
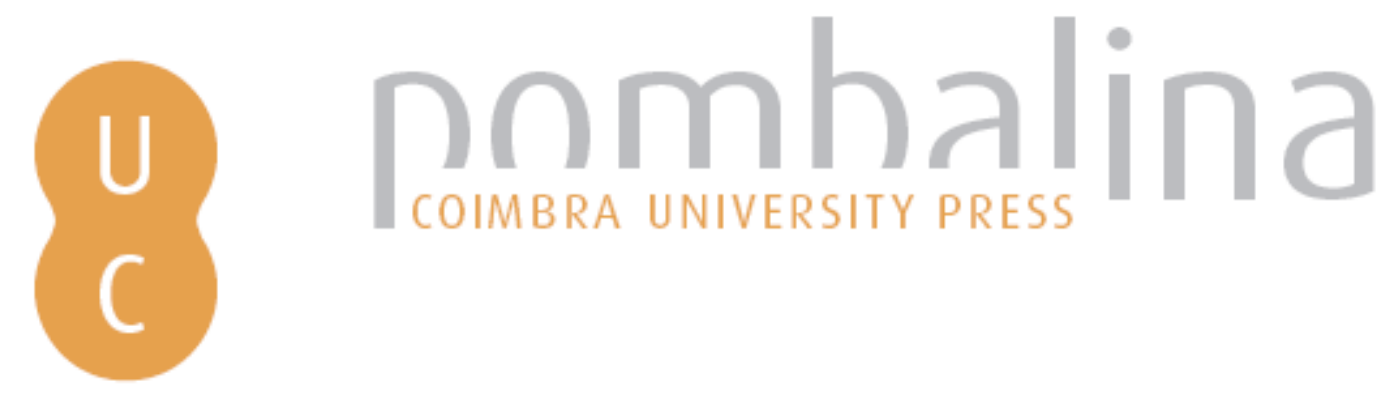

\title{
O conceito de política na tradição republicana
}
Autor(es):
Giorgini, Giovanni
Publicado por: Imprensa da Universidade de Coimbra
URL
persistente:
URI:http://hdl.handle.net/10316.2/30850
DOI:
DOl:http://dx.doi.org/10.14195/978-989-26-0497-8_1

Accessed : $\quad$ 26-Apr-2023 10:56:47

A navegação consulta e descarregamento dos títulos inseridos nas Bibliotecas Digitais UC Digitalis, UC Pombalina e UC Impactum, pressupõem a aceitação plena e sem reservas dos Termos e Condições de Uso destas Bibliotecas Digitais, disponíveis em https://digitalis.uc.pt/pt-pt/termos.

Conforme exposto nos referidos Termos e Condições de Uso, o descarregamento de títulos de acesso restrito requer uma licença válida de autorização devendo o utilizador aceder ao(s) documento(s) a partir de um endereço de IP da instituição detentora da supramencionada licença.

Ao utilizador é apenas permitido o descarregamento para uso pessoal, pelo que o emprego do(s) título(s) descarregado(s) para outro fim, designadamente comercial, carece de autorização do respetivo autor ou editor da obra.

Na medida em que todas as obras da UC Digitalis se encontram protegidas pelo Código do Direito de Autor e Direitos Conexos e demais legislação aplicável, toda a cópia, parcial ou total, deste documento, nos casos em que é legalmente admitida, deverá conter ou fazer-se acompanhar por este aviso.

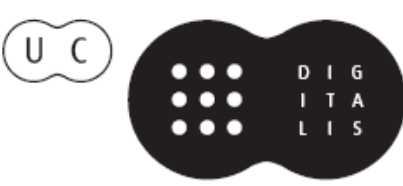


Armando Malheiro da Silva

Maria Luiza Tucci Carneiro

Stefano Salmi

Coordenação

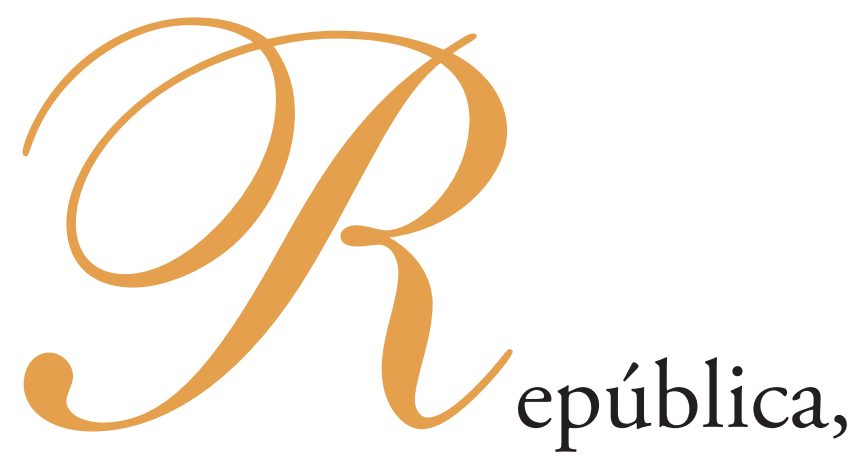

Republicanismo

e Republicanos

Brasil • Portugal • Itália 


\section{Giovanni Giorgini}

\section{O CONCEITO DE POLÍTICA NA TRADIÇÃO REPUBLICANA}

É possível fixar uma data de nascimento da política? A resposta depende, naturalmente, da acepção que damos ao termo "política". Se o entendemos como um simples sinônimo de associação de homens, estar junto por determinação da sociabilidade humana, do que deriva uma subdivisão de tarefas e uma organização de poder, então a política é eterna, tão antiga quanto o homem. Nesse sentido, pode-se falar, por exemplo, da "política" dos soberanos na civilização palaciana cretense. Se, por outro lado, acolhemos este termo em sentido estrito, recuperando sua etimologia de polis - cidade - e polites - cidadão -, então a política nos é dada historicamente e constitui um modo de associação humana contraposto, por exemplo, ao governo despótico: não existe política nas imensas vastidões da Ásia porque lá não existe uma verdadeira comunidade política nem cidadãos, uma vez que apenas um é livre enquanto todos os outros são escravos. Nesse sentido, o termo está ligado ao conceito de liberdade e participação do poder e contraposto à tirania: é exatamente nessa segunda acepção que o termo é usado pelos autores republicanos. A distinção remonta a Aristóteles, que entendia que a "politicidade", em sentido genérico de sociabilidade, não era uma característica unicamente humana e que as abelhas, por exemplo, fossem animais extremamente "políticos", já que eram incapazes de viver sozinhos. Típica dos homens, por outro lado, é a política como delimitação de um espaço público do qual todos os cidadãos, em linha de princípio, participam: política, portanto, ligada à polis, à agorà, à dimensão do koinon. A política assim concebida é contraposta por um lado à dimensão privada, na qual os homens vivem uma vida 
meramente biológica e não podem realizar suas potencialidades tipicamente humanas: estas, assim como alcançar a felicidade, são realizáveis somente na dimensione pública. Por outro lado, a política é contraposta ao "despotismo oriental", no qual o soberano reina sobre súditos escravos por natureza, e à tirania. Em sentido mais específico, a política é concebida como a esfera onde se realiza o governo (autogoverno) da cidade e a esfera em que se discute e delibera sobre coisas que dizem respeito a todos os cidadãos (chamadas simplesmente ta pragmata), a dimensão em que se conciliam os conflitos (política oposta à guerra), espaço de participação e de mediação submetido à autoridade objetiva da lei e oposto ao arbítrio do indivíduo: a política nesse sentido implica publicidade e participação e é contraposta à tirania em todas suas instâncias. É possível encontrar os primeiros passos de uma consciência política na reforma constitucional feita em Atenas por Sólon (594 a.C.), que aboliu a escravidão por dívidas e chamou de volta à pátria os cidadãos atenienses vendidos como escravos no exterior, sancionando assim o princípio fundamental segundo o qual o corpo do cidadão não podia mais ser dado em penhor. O desenvolvimento da consciência política na Grécia, planejada em cada uma de suas etapas, mas não preestabelecido em seu conjunto, conhece alguns momentos culminantes notáveis - a reforma de Clístenes em 508 a.C., o golpe de Estado de Efialtes e Péricles em 461 a.C. — e com Platão (427-347 a.C.) e Aristóteles (384-322 a.C.) já temos uma teoria política, além de uma imagem idealizada da polis e da política, um "deve ser" que, pela distância no tempo e a sedução da exposição, frequentemente ofuscou a realidade histórica, exercitando uma influência poderosa e duradoura no pensamento político ocidental de todas as épocas.

Nem sempre os estudiosos deram destaque suficiente ao duplo nível sobre o qual se move o estudo aristotélico da política, cuja contínua influência nos séculos é ainda hoje evidente, tanto que os autores denominados Comunitários julgaram poder utilizá-lo como corretivo, ou até mesmo como alternativa, para as posições liberais. Aristóteles, de fato, deixou-nos como herança uma poderosa visão, tanto da política como prática efetiva do poder dentro da polis, quanto da "ciência política", compreendida como a ciência que identifica os princípios do viver político e se propõe, portanto, aconselhar a política entendida como prática. Na primeira acepção, a política é concebida como arte mais "arquitetônica", uma vez que controla as outras artes que tem como finalidade a virtude 
e a felicidade (Ética a Nicômaco I 1, 1094b). É bom destacar como a imagem que ele nos propõe na política represente uma idealização da prática real da época (aliás, de uma época, a da polis, já sobrepujada pelo alargamento do horizonte político realizado pelas conquistas de Alexandre), uma visão na qual o ser e o dever ser são dificilmente dissociáveis, mas que, talvez exatamente por isso, têm um fascínio e uma atração irresistíveis. Ele parte da definição de polis como comunidade (koinonia) natural caracterizada, diferentemente da família e do vilarejo, por ser autossuficiente e, portanto, capaz de permitir ao indivíduo realizar as potencialidades que qualificam o homem como tal: o homem é, "por natureza, um animal político" (I 2, 1253a) e quem não está apto a viver na polis ou não sente necessidade disso é "um deus ou um animal feroz". Para ele é fundamental a distinção entre polis e casa (oikos), distinção esta que marca uma diferença muito nítida com o mestre Platão, que havia identificado arte política com a do dono da casa e pai de família (Politico): para Aristóteles, a polis é a dimensão "horizontal" do koinon, na qual os seres humanos (homens, adultos e livres, naturalmente) participam sob o mesmo pé de liberdade e igualdade da vida pública e das deliberações comuns (cidadão, polites, é quem senta nos tribunais e é eleito para os cargos públicos. III 1, 1275a; III 13, 1284a); a oikos individua uma dimensão privada caracterizada por relações "verticais", como aquelas entre pai e filho e entre senhor e escravo. A natureza do cidadão depende da constituição (politeia) da comunidade política em que vive, pois a politeia identifica não apenas o ordenamento das magistraturas e a autoridade suprema, mas também a alma, o próprio princípio vital da cidade: o bom cidadão varia conforme a constituição (III 4, 11276b-1277a). Observando aqueles que detêm o poder supremo, Aristóteles identifica seis formas de politeia, três justas (Monarquia, Aristocracia, politeia) e três corrompidas (Democracia, Oligarquia e Tirania), dependendo se os governantes visam o interesse comum ou pessoal. Tendo surgido para permitir a sobrevivência, a polis, no entanto, tem como finalidade a "boa vida", ou seja, uma existência plenamente realizada e independente (III 9, 1280a). Aristóteles entende, portanto, que qualquer estudo das "coisas concernentes à cidade" não pode se eximir de examinar qual a melhor forma de governo, adequada a assegurar a felicidade dos cidadãos. Ele a identifica, não sem oscilações teóricas devido à natureza "aproximativa" da matéria, em uma forma mista, posicionada entre a aristocracia e a politeia, na qual prevaleça a classe 
média (IV 11, 1296a) e o governo seja feito pela lei, que é "razão sem paixão" (III 16, 1287a). Teoricamente, o reinado parece a melhor forma de governo, mas somente se o rei possuir virtudes tão extraordinárias a ponto de parecer quase um deus entre os homens: Aristóteles sabe que em política é muitas vezes oportuno abandonar "o melhor" pelo "melhor nas atuais circunstâncias". Duas observações conclusivas. É preciso destacar como Aristóteles retoma a tradicional condenação da tirania herdada das lutas políticas atenienses e lhe dá fundamento teórico, contribuindo assim para criar o topos segundo o qual a tirania constitui a própria negação da política. Não devemos esquecer, por fim, que a vida política constitui a pré-condição, uma vez que só em uma boa forma de governo o indivíduo pode ser virtuoso, mas não a realização da felicidade humana: esta consiste, por outro lado, segundo a célebre conclusão da Ética a Nicômaco, na vida contemplativa, que aproxima o Homem de Deus e o torna, o quanto possível para a natureza humana, imortal (athanatizein: E.N. X 7, 1177b).

O historiador Políbio acredita que da história "pragmática" (I, 2) possa emergir uma lição duradoura de política, uma vez que esta ensina como depende da forma de governo o sucesso e o destino de um povo: o homem político pode assim fazer previsões seguras para o futuro. Ele, como se sabe, entende que a melhor forma de governo seria uma forma "mista" que resultasse da sábia mescla das três formas justas simples - Monarquia, Aristocracia e Democracia. Esta forma mista, encarnada historicamente na República romana, é a mais estável, a menos sujeita ao suceder-se cíclico que caracteriza as formas simples (anaciclose), além de ser a mais adequada para assegurar a liberdade e o bem-estar dos cidadãos.

O termo "política" não tem larga circulação na literatura latina, onde nunca aparece em autores como César, Lívio, Salústio e Tácito. Isso não significa, obviamente, que também esteja ausente o conceito. Falta um termo que tenha a intensidade do grego politikon, mas diversos vocábulos capturam suas nuances semânticas, em particular civilis. Cícero, ao qual devemos a tradução em latim da quase totalidade dos conceitos filosóficos e políticos gregos, nos mostra que "politicum" é um grecismo em De oratore III, 109, onde diz significativamente que aquilo que os gregos chamavam "políticos filósofos" possuíam uma "eximiam rerum maximarum scientiam". Cúrzio afirma — em Epistulae ad familiares VIII, 1, sobre Cícero - "tui politici libri omnibus vigent" (teus livros políticos são apreciados por todos). Essas são as únicas duas ocorrências do termo em 
todo o corpus ciceroniano. Ele, porém, nos coloca em um bom caminho para investigar o conceito de política junto aos latinos quando, em duas passagens do De finibus, sustenta que "civilem" é a tradução do grego politikon (IV, 5), acrescentando que "civile atque populare" substitui plenamente o significado do termo grego (V, 65). (Há uma anotação semelhante em Apuleio de Madaura, que nos informa que "civilitatem" é a correta tradução do grego politiken: De Platone et eius dogmate II, 8). É, portanto, ao adjetivo civilis que devemos prestar atenção: descobrimos assim que a ciência política é a scientia rerum civilium (De re publica I, 11; I, 13; I, 34); a sabedoria política e a sensatez prática constituem a civilis prudentia (II, 45; II, 51-52), enquanto a vida política é retribuída com vida civil (III, 6). Questão terminológica à parte, se quisermos capturar a verdadeira essência do conceito latino de política convém voltar mais uma vez a Cícero. Nele encontramos tanto o apaixonado amor à pátria, que faz com que ele entenda que o sábio não deve negligenciar a ciência política (rerum civilium scientiam) que um dia poderá utilizar para se tornar útil à República, seja a visão estóica da kosmopolis ou a verdadeira pátria do sábio (I, 13). Sua concepção política é centrada sobre a noção, justamente famosa, de res publica como res populi, onde o povo não é "uma multidão de homens reunidos de um modo qualquer", mas sim uma sociedade organizada, que surgiu de uma inclinação natural a viver junto, "que tem como fundamento a obediência ao direito e interesses em comum" (De re publica I, 24): encontramos nessa definição tanto o tema aristotélico do zoon politikon (traduzido como naturalis quaedam hominum quasi congregatio) quanto o motivo tipicamente romano da centralidade do direito (ius). Cícero entende ser a igualdade de direitos (iuris societas) que distingue a comunidade política, mesmo quando existem desigualdades naturais e de riqueza (I, 32): essa igualdade se traduz em um ideal de autogoverno no qual um povo livre e esclarecido escolherá como governantes os homens melhores, criando um regime misto. Portanto, nos lugares em que o poder esteja nas mãos de um tirano ou de uma facção falta o vínculo do direito e a res publica não existe mais (III, 31). A visão da política ciceroniana alcança seu auge no Somnium Scipionis, onde se afirma que está reservado um lugar especial no céu aos políticos que salvaram, ajudaram e engrandeceram a pátria, porque nada agrada mais à divindade do que "aliados políticos juridicamente constituídos chamados civitates" (VI, 3). 
Para o historiador Salústio, testemunha das guerras civis entre Mário e Sila, e mais tarde entre César e Pompeu, a concórdia é, por excelência, a virtude política constitutiva da comunidade política ("ita brevi moltitudo diversa atque vaga concordia civitas facta erat": De coniuratione Catilinae 6). Quando esta não existe, está aberto o caminho, no Estado, para todos os males, corrupções e perversões: estes são encarnados na figura de Catilina, que resume todos os valores contrários aos que tornaram grande a Roma republicana. Em sua obra, o passado republicano é idealizado através do contraste com a figura de Catilina: seu projeto de se apoderar da República para baixos objetivos pessoais consente delinear, per contrarium, a visão política republicana, certamente idealizada, na qual reinava a justiça e a concórdia, a moral era observada por um impulso natural e os cidadãos competiam por sua capacidade (Cat. 9).

No século XIII, o renascimento do conceito de política elaborado a partir do pensamento greco-romano, exposto nas obras de Aristóteles e Cícero e codificado no direito romano, aconteceu em nome da liberdade civil diante das ameaças de tirania. A visão de política herdada da antiguidade clássica era contraposta ao governo tirânico em todas suas formas: o viver político é caracterizado pelo governo da lei, que previne o arbítrio e modera as paixões. É por isso que John Fortescue (1409-1476 ca.), em seu De laudibus legum Angliae, pode falar de "dominium politicum et regale" para caracterizar a restrita Monarquia britânica em contraposição ao "dominium regale" do nascente absolutismo francês. Fundamental importância teve a tradução para o latim das obras aristotélicas, feitas por Roberto Grossatesta (Ética a Nicômaco) e Guglielmo di Moerbeke (Politica), que produziu uma renovada influência do pensamento aristotélico na reflexão política. A incerteza de Tomás de Aquino ao traduzir a expressão aristotélica "politikon zoon", traduzida como animal sociale et politicum no De regimine principum e tanto como animal sociale quanto como animal politicum na Summa theologiae testemunha a falta do referente da política aristotélica - a polis - como também a perda de significação do termo "político", que hoje é preciso traduzir recorrendo a dois adjetivos. Como destacou Maurizio Viroli, a obra de Macróbio Comentário ao sono de Cipião constitui a ponte entre a reflexão política romana e o pensamento republicano tardio-medieval. Nessa obra é retomada a visão ciceroniana das virtudes tipicamente políticas - prudência, firmeza, temperança, justiça - que identificam o verdadeiro homem político, 
com particular ênfase na relação entre virtude política e obtenção da felicidade. A Justiça e o consequente respeito pelas leis tem um papel primordial entre essas virtudes, como é afirmado no tratado anônimo Oculus pastoralis (1222 ou 1242): são os princípios da sabedoria política (civilis sapientiae) que, realmente, mantém unida a sociedade.

O Defensor da paz (1324), de Marsílio de Pádua, constitui um eficaz termômetro para avaliar a recepção tardo-medieval e o afastamento da doutrina aristotélica. Retomando a clássica subdivisão em formas justas e formas "viciadas", Marsílio torna veladamente conhecidas suas preferências tratando da politia, assim definida por ele:

"se bem que haja, em certo sentido, algo que é comum a todo tipo ou gênero de regime ou governo, em outro sentido indica um certo tipo de governo temperado no qual cada cidadão participa de alguma maneira do governo ou da função deliberativa segundo sua classe, sua habilidade ou condição, para o benefício comum e com a vontade ou consenso dos cidadãos" (I, 8, 3);

definição da qual emerge sua visão da participação da universitas civium (ou da valencior pars) na função de governo como também a noção de que seja "político" o que visa o benefício comum (I, 9, 6). Em Marsílio encontramos estreitamente ligadas a visão da política como arte da legislação — onde "lei" também significa "a ciência ou doutrina ou juízo universal do que é justo e civilmente vantajoso e de seu oposto" (I, 10, 3) - e a ideia de que o governo da lei seja o fundamento de toda a forma de governo justa: a política é, assim, concebida novamente como arte "arquitetônica" em sentido aristotélico ao passo que a "prudência" reencontra seu papel central entre as qualidades do homem político.

Essa visão da política como a mais alta das artes, uma vez que consente alcançar o supremo bem da comunidade, constitui o leitmotiv do humanismo cívico italiano. Mas já anteriormente, em Livres dou Tresor de Brunetto Latini, a política era considerada a mais alta das ciências humanas, pois reúne os ensinamentos sobre governo; é sua a famosa definição de política como arte de governar uma República de acordo com a Justiça e a razão. Em geral, os humanistas identificam o "viver político" com um regime republicano no qual os cidadãos participam, em plano de igualdade, na formulação das leis e na eleição dos magistrados, 
garantia de Justiça e concórdia: tal regime de liberdade é por ele considerado o oposto da tirania. Coluccio Salutati considera a política a mais alta expressão da racionalidade humana. Em suas obras encontramos a clássica contraposição entre a escravatura provocada pela tirania e a "dulcissima libertate" de que gozam os cidadãos de um governo político, caracterizado pela existência de leis justas. Em seu pensamento, a política identifica-se com as leis, sobre as quais se apóia toda a estrutura da sociedade. No Laudatio de Leonardo Bruni reencontramos a visão tipicamente humanista da política como arte que contém os praecepta circa rempublicam, ou seja, as indicações que regulam o autogoverno dos cidadãos. Essa obra, mais que descrever a realidade florentina, celebra o ideal bruniano de cidade onde o harmônico equilíbrio das instituições preserva a liberdade e a igualdade dos cidadãos, em que a inviolabilidade da lei exorciza o perigo de tirania. Temas clássicos como o elogio da concórdia e o ódio pela facção e pelo interesse de parte, que destroem a vida civil e a "doce liberdade" do cidadão, a exaltação da Justiça como virtude fundamental de uma República bem ordenada, estão presentes na Vita civile de Matteo Palmieri, escrita entre 1435 e 1440. A altíssima consideração que ele tem pela vida pública emerge com toda a clareza em sua visão de que, quando um "bom cidadão" ingressa em uma magistratura, cessa de ser um indivíduo privado para encarnar "universal identidade de toda a cidade", para se tornar um "animata republica" (Vita civile: 132). Em Alamanno Rinuccini, por outro lado, é enfatizado o valor da inviolabilidade da lei, na qual a obediência é o fundamento de todo o "buono et polytico viver" (Lettere ed orazioni: 191); repetindo Cícero, que por sua vez retomava uma sugestão de Heródoto, Rinuccini identifica a liberdade do cidadão com a obediência às leis. Uma dicotomia de fundo, entre arte política e arte do Estado, permeia todo o Trattato circa el reggimento e governo della città di Firenze de Girolamo Savonarola, o qual reflete a dicotomia entre o "governo civil", baseado na Justiça e na benevolência e devotado ao bem comum e a tirania, em que tudo acontece arbitrariamente e distante da dimensão pública (nos "segredos de Estado").

Na figura e na obra de Niccolò Maquiavel estão representados o momento histórico do surgimento do modelo alternativo da "razão de Estado", que parece estar na base da visão não unívoca, aliás dramaticamente dividida da política, que emerge de suas duas obras políticas principais. Além disso, é difícil separar seu pensamento da história de sua recepção: simplificando ao máximo, todavia, 
pode-se plausivelmente afirmar que a visão política que encontramos em suas obras é fundamentalmente unitária, como são únicas as categorias conceituais pelas quais ele examina a complexa matéria política. No Príncipe, porém, Maquiavel descreve as condições mínimas necessárias para a existência da autêntica "política", cuja natureza e fins serão expostos nos Discursos: a própria existência do Estado, a cuja sobrevivência o príncipe deve dedicar todos os cuidados, sabendo "entrar no mal necessário": não é possível haver política se não existe, prioritariamente, a comunidade política. No Príncipe, ele examina, portanto, o "grau zero" da politicidade, que no entanto ainda não é o "viver político"; tanto é verdade que Maquiavel nunca usa o termo "político" nesta obra. Além da mera existência, que é o pré-requisito essencial, é preciso que a comunidade política não seja corrupta, ou seja, que não existam facções nobiliárias que não permitam a participação dos cidadãos no poder e o autogoverno: esses são, de fato, os traços fundamentais do "viver livre" elogiado nos Discursos. Onde há desigualdade, onde existem "fidalgos que comandam do alto" (Discursos I, 55), é necessária uma "mão régia ou quase régia" e o recurso a "homens muito extraordinários" (I, 17) para refrear a ambição dos poderosos e trazer de volta a igualdade à comunidade política. A paixão republicana de Maquiavel, nunca, porém, separada do realismo político, aparece com toda a evidência no cap. 58 do livro I dos Discursos, onde ele conclui "contra a opinião comum" afirmando a superioridade do governo do povo sobre o de um príncipe, desde que tal governo seja moderado e regulado pelas leis, mas reconhece a superioridade dos príncipes "em dispor leis, formar vidas civis, dispor estatutos e novas ordens". O "viver político", contraposto ao poder absoluto de um tirano, é possível, portanto, tanto em uma república quanto em um principado nos quais não haja corrupção, ou seja, o interesse público não seja subordinado ao privado, ao particular; o "viver livre", por outro lado, é característico apenas das Repúblicas. Assim, é importante a relação entre política e religião: esta última tem um papel educativo que nunca deveria ser separado do viver civil, já que poderia levar os homens a procurar a glória mundana na atividade política; disso deriva sua opinião crítica sobre a religião cristã, culpada de ter "afeminado o mundo e desarmado o Céu" (Discursos II, 2), provocando desinteresse pelas coisas terrenas. Maquiavel tem, por fim, uma aguda consciência da seriedade da política, porque esta tem como finalidade a sobrevivência e o bem-estar de toda a 
comunidade, do "universal": como bem mostrou Nicola Matteucci, "a política não é o ser contraposto ao dever ser da moral, mas possui uma obrigatoriedade própria, interna e intrínseca" (Matteucci 1984: 59) e, justamente pela grandeza de sua tarefa, pode até pedir ao verdadeiro homem político a "condenação de sua alma".

No Proêmio de seu Dialogo del reggimento di Firenze (Diálogo do governo de Florença), Francesco Guicciardini elogia a política como única disciplina que consente ao homem realizar seus fins mais elevados, da qual, aliás, "depende o bem-estar, a saúde, a vida dos homens e todas as ações egrégias que são feitas nesse mundo inferior" (:299). Nessa obra, Guicciardini expõe a visão republicana canônica da arte política como arte da cidade e propõe o governo misto como forma perfeita de governo. Maurizio Viroli mostrou convincentemente como Guicciardini entendia que política e arte do Estado fossem baseadas em duas interpretações incompatíveis da identidade da cidade e destacou, ao mesmo tempo, como Guicciardini soube alternar os dois registros e adotar a linguagem mais apropriada conforme as circunstâncias. É fato conhecido, enfim, como ele era inimigo de qualquer fórmula geral em política, convicto que somente a experiência pudesse ensinar o "discernimento" que consente ao homem político entender as peculiaridades de cada nova situação: em política não existem regras, pois a exceção e a novidade são a regra.

Antonio Brucioli retoma a visão aristotélica de política como arte do bom governo, a arte de construir e manter uma comunidade política na qual os homens possam viver uma vida virtuosa; isso é possível principalmente em uma república, na qual todos os cidadãos participam das decisões públicas em plano de igualdade. O débito em relação a Aristóteles - com sua ênfase no papel da amizade política, sua ideia de virtude como meio-termo e a identificação do regime perfeito com uma cidade na qual a classe média prevaleça - é evidente também na visão de Brucioli de República perfeita, identificada com uma comunidade de cidadãos "medíocres" ligados por um certo tipo de amizade. Uma abordagem não apenas teórica pode ser encontrada em Donato Giannotti, secretário do Conselho dos Dez de Florença, para o qual a arte política tem como objetivo principal restaurar uma cidade corrompida; para tal finalidade, é necessário um sistema constitucional bem equilibrado, no qual nenhum elemento resulte preponderante. Em Della perfezzione della vita política (Sobre a perfeição da vida política) de Paolo Paruta encontramos uma celebração da excelência 
da vida civil, enquanto a política, ciência da vida virtuosa, é ciceronianamente definida "verdadeira Filosofia".

Spinoza entende que a comunidade política nasça com a finalidade de ajuda mútua, da divisão do trabalho. Privados de ordenamento político, os homens vivem em um estado de barbárie, em uma condição infeliz e quase animalesca (Tratado teológico-político 5). A incapacidade de obter o próprio proveito de acordo com a estrita razão torna necessários o poder coativo e a lei. Retomando uma argumentação aristotélica, ele afirma que a melhor maneira para preservar a liberdade do povo é exercitar coletivamente o poder, a menos que apareça alguém dotado de qualidades superiores ao humano. Ele considera "nocivo para um povo não habituado a viver em regime monárquico e que já possua leis próprias, eleger um rei" (cap. 18).

A política como arte do bem governar, como filosofia civil, sucumbe sob o inexorável avançar da arte do estado que por todo o século Xvi havia vivido em sua sombra. Trata-se de uma mutação do horizonte político que acontece de acordo com modalidades diversas nas diferentes áreas geográficas que compõem a Europa moderna; a alternância de política e arte do estado, ou seja, de filosofia e razão de Estado, resulta plenamente acabada onde triunfam, no pensamento e na prática da política, claros mecanismos de produção das decisões políticas em detrimento dos códigos constitucionais; uma ampla literatura política documenta o recurso do príncipe e de seu conselho privado nos arcana imperiorum, ou seja, aquela zona indistinta de política e arte do Estado à qual os súditos não tinham acesso; tratava-se de um fenômeno novo, que rompia com uma concepção de política de longa tradição.

É de destacar que particularmente na Inglaterra se assiste, no curso do século XVII, a uma intensificação da reflexão política sob o impulso de circunstâncias e condições políticas que logo levarão à execução de um rei: a idade das guerras civis de religião, antes na França, depois na Holanda e na Inglaterra, é testemunho da dificuldade de encontrar equilíbrios políticos dentro de uma transição requerida pela modificação das condições sociais e materiais; é testemunho, porém, da insuficiência das elaborações ideológicas que tentavam recuperar, entre os escombros de uma tradição intelectual veneranda, as linhas essenciais para a construção de um modelo político adequado ao presente. O pensamento político inglês, diante da crise da política, reagiu seguindo linhas diretivas diferentes; 
em parte procurando na antiguidade imemorável da história anglo-saxônica instrumentos eficazes de legitimação de um poder novo, em parte readequando ao horizonte político modificado a antiga doutrina do direito divino do rei, em parte - e essa foi a opção republicana - buscando na tradição veneranda da política como filosofia civil uma linguagem capaz de reparar as divisões entre as facções e consentir a todas as partes em conflito uma convergência sobre questões basilares da coexistência civil.

Mas antes de nos aprofundarmos nesse sentido, é preciso colocar em evidência como o quadro seria posteriormente perturbado por se delinear no horizonte uma teoria política que substancialmente não tinha raízes na história européia. Partindo do pressuposto que nada era devido à "antiguidade em si mesma" (Leviatã: 699), Thomas Hobbes elaborava uma concepção de política original e revolucionária: foi a própria autocompreensão filosófica da teoria hobbesiana a fixar a política como a ciência não mais antiga do que o livro "quem De Cive ipse scripsi".

Hobbes rompe, portanto, nitidamente com a antiga tradição de política, que ele parece julgar um longo e inconclusivo preâmbulo a seu livro De cive, ao qual, por outro lado, nada era devido. Mas se sente mais a ruptura com a tradição onde Hobbes, postulando uma antropologia pessimista, solicita ao indivíduo um pesado investimento de energias (de paixões e de cálculo) para sair do estado brutal de natureza e, através de um contrato, faz com que ele renuncie à sua politicidade natural (que só gera conflito e destruição) para fazê-lo ingressar na condição civil cujo único objetivo "político" é a conservação da vida: em conclusão - como observou com perspicácia Manfred Riedel — na gênese filosófica do argumento contratualista encontra-se a extinção da forma de racionalidade especificamente aristotélica, pela qual "o único ato político notável a essa "ciência nova" - a constituição da razão política na união originária dos cidadãos (unio civilis) — é ao mesmo tempo a extinção da autonomia racional da ação política" (Riedel, 1990: 161).

Os autores que, no mesmo período, tentavam relançar um léxico republicano, alimentado pela tradição veneranda da filosofia civil, perceberam a excepcionalidade de Hobbes e colocaram-se conscientemente em aberta polêmica com suas conclusões. Tratava-se, em outras palavras, de reverter o argumento hobbesiano da impoliticidade do cidadão, da ruptura traçada por Hobbes entre Estado e indivíduo, público e privado, para demonstrar - acompanhando Aristóteles — que 
o indivíduo é bom (isto é, político) por natureza e que essa politicidade é conservada no Estado, aliás, é a mola que faz funcionar o mecanismo do Estado.

É principalmente James Harrington que adverte com maior consciência teórica a exigência de conservar inabaláveis distinções no cânone clássico-republicano e, em última instância, de "salvar" a autonomia da ação política que Hobbes havia suprimido. O que estava em jogo era ainda a "política" como filosofia civil, ou melhor, a possibilidade, já imprecisa, de datar sua origem antes de De cive. Tratava-se, portanto, de construir uma nova genealogia cultural que pudesse demonstrar a não transcendibilidade da política clássica, a possibilidade de representar sua história em um continuum não interrompido. A insistência de Harrington sobre o caráter heterodoxo da filosofia de Hobbes visava conservar intacta a antiga tradição de política que Hobbes havia relegado à pré-história da política, em uma antiguidade remota e destacada da realidade. Tratava-se, para Hobbes, de lançar novas bases para edificar a nova cidade política, mas esta cidade surgia despojada dos vestígios de um passado que para os republicanos remontava à Roma antiga.

Por isso, Harrington olha para o passado, para o ensinamento dos antigos e de "seu sábio discípulo Maquiavel (o único verdadeiro estudioso político dos tempos passados)" (Oceana: 101), sua doutrina pode ser exemplificada assim: que o governo seja "o domínio dos homens e não das leis", que a arte de governar seja baseada "no direito ou no interesse comum" e que a teoria das formas de governo reproduza o modelo clássico, são todos dados a interpretar à luz dos débitos culturais do autor, de sua confiança "filosófica" na incontrovertibilidade da "doutrina dos antigos".

Exemplar do clima incandescente que segue a execução de Carlos I Stuart é a controvertida obra de John Milton que monopoliza argumenta de fontes cuidadosamente selecionadas. Trata-se, obviamente, de Aristóteles e dos "melhores escritores políticos" (The Tenure of Kings and Magistrates: 202), que são, inevitavelmente, Lívio, Cícero e os Pais da Igreja. Por toda a vida, desde as primeiras melancólicas reivindicações regicidas até à amarga tomada de posição antimonarquista de The Ready and Easy Way, permanece viva a exigência de exprimir o valor das liberdades políticas dentro de uma República.

Entre os autores posteriores ao cânone clássico-republicano, maior destaque têm as figuras de Algernon Sidney, Henry Neville e Walter Moyle, que 
caracterizam uma época de busca por novos posicionamentos ideológicos, nos quais parece ter-se diminuído a tensão ideal que havia animado os primeiros projetos de constituição republicana: sobretudo, Moyle procura ler em detalhes as contradições de seu tempo - a coexistência problemática de Estado e religião na Inglaterra nos anos que se seguem à Glorious Revolution - e observa o modelo da Roma antiga. Uma vez que "a religião dos romanos era uma parte de sua política [policy]" (Essay: 215), as suas instituições eram constitucionalmente preservadas da discórdia e da revolta, que se manifestam onde os interesses do clero se colocam em contradição com os da "consciência nacional". Moyle afirma, por isso, que "é contra qualquer regra da política perseguir as opiniões que não sejam destrutivas da sociedade humana, já que uma consequência necessária de uma prática do gênero é a limitação da base da comunidade através do enfraquecimento do poder e da força de uma república" (ibidem).

Falta dizer que o périplo da reflexão republicana na Inglaterra somente terminará por volta da primeira metade do século XVIII, quando a lição dos autores examinados encontrará um terreno mais fértil na América. Concluída a experiência da República inglesa, a ampla herança dos autores mencionados dissipa-se no milieu intelectual do qual germinarão as primeiras centelhas da revolução americana, ou seja, do evento que foi definido por uma influente historiografia como o último grande ato do humanismo civil.

Em Montesquieu, o termo política é usado na clássica contraposição política versus condição despótica ou dominium. Assim, em sentido geral, "direito político" é o direito que regula as relações entre governo e governados, e "estado político" é uma sociedade dotada de governo (O espírito das leis I, 3). Em sentido mais próprio, no entanto, "estado político" é sinônimo, em Montesquieu, de "estado republicano", baseado na virtude, independentemente do princípio de governo, democrático ou oligárquico (V, 2). Nesse uso, Montesquieu conecta-se novamente à tradição semântica pela qual "político" é aquilo que é inerente à politeia, um âmbito, uma esfera do agir, distinta e contraposta às relações de poder.

Quase espelhando a intrigante duplicidade que levou os estudiosos a ver nele tanto o último defensor da virtude política clássica quanto o precursor da moderna "democracia totalitária" e do totalitarismo, o conceito de política que vemos em Jean-Jacques Rousseau é absolutamente dicotômico, uma vez que apresenta uma acepção positiva e uma negativa. Esta última é visível na primeira obra que 
lhe deu celebridade, o Discurso sobre a origem da desigualdade entre os homens, no qual a política é contraposta, como condição alienada, ao estado de natureza: a sociedade e as leis destroem inevitavelmente a liberdade natural do homem, aumentam seus desejos e necessidades, e diminuem, ao mesmo tempo, a possibilidade de satisfazê-los, reduzindo-o a uma condição servil. Essa visão retorna no Contrato social na famosa asserção da condição de escravidão do homem na maior parte das comunidades políticas modernas. Se procurarmos uma visão positiva de política na obra de Rousseau, encontraremos sempre presente a ideia de que a verdadeira política é aquela que faz coincidir o homem com o cidadão. Isso pode acontecer apenas em uma sociedade que tenha sido instituída através de um contrato na qual a vontade geral, tendo em vista o bem comum, não submete o indivíduo aos desejos arbitrários de outros homens: nessa sociedade cada um é submetido unicamente à própria vontade. Ele vê na constituição democrática "a obra-prima da arte política" (Cartas escritas da montanha 8). A sociedade civil é um estado de conflito determinado pelos diversos desejos e pela competição entre os seres humanos. Uma vez tendo saído do estado de natureza não se pode deixar a sociedade, pode-se somente torná-la melhor.

Com Rousseau, assistimos a uma profunda transformação da semântica tradicional da política. A "sociedade política" ou o "corpo político", em Rousseau, são originados por um pacto de alienação, por uma "primeira convenção" ou pacto social, no qual prevalece a "vontade geral" do povo soberano. No pensamento rousseauniano, que pertence à tradição do moderno direito de natureza racional, a esfera "política" não se define mais na contraposição clássica ao domínio e ao poder de fato, mas através da fictio da soberania representativa, que gera uma nova figura: o citoyen, que existe na medida em que participa da autoridade soberana e, ao mesmo tempo, súdito, na medida em que está submetido às leis do Estado (O contrato social I, 6). "Verdadeiros princípios do direito político", portanto, são aqueles (enunciados na obra) que conduzem ao reconhecimento da vontade geral (VI, XI). Corpo "político" ou República torna-se sinônimo de corpo soberano, leis "políticas" ou leis fundamentais são as que regulam "a relação do todo com o todo ou do corpo soberano com o Estado", ou seja, constituem "a forma do governo" (II, XII). O "princípio da vida política", lemos por fim, "é a autoridade soberana" (III, XI). O uso do termo política, em Rousseau, aparece assim ligado inseparavelmente à reconfiguração da ideia de 
res publica no léxico teórico da fundação contratualista da soberania: político é o que diz respeito ao Estado, à soberania, à esfera pública, assim gerados.

No pensamento revolucionário, o conceito de política, sempre a partir da centralidade da ideia de povo soberano, reassume o sentido clássico de atividade coletiva da criação e da tutela do espaço público, com uma forte ênfase na participação e na prioridade da "vontade geral" sobre qualquer interesse particular.

Em Siéyés, político é o que é pertinente à "Nação", que transcende as vontades individuais, uma vez que uma associação política "só pode ter um interesse geral" (Ensaio sobre privilégios). Através da representação, que é política enquanto traz à luz unicamente a vontade comum, tal unidade toma corpo, como soberania da nação, nos órgãos eletivos. Política é, tanto em Siéyés quanto em Rousseau, "a vontade geral da Nação", as formas e as instituições representativas que dão voz a ela e, em geral, a dimensão em que se realiza unidade e comunhão de objetivos entre cidadãos.

Essa retomada por via representativa do antigo sentido de política como res publica é acompanhada nas diversas expressões do pensamento revolucionário com a retomada do tema da participação do citoyen e de sua virtude cívica, que se conecta de modo orgânico à ênfase sobre a "vontade geral". Como podemos ler em Mably (Sobre a legislação): "talvez não seja verdade que a política deve nos fazer amar a virtude, e que esse é o único objetivo que devem se propor os legisladores?" A política como expressão e tutela da vontade geral contra o particular termina, assim, por se identificar com a virtude e vice-versa. Robespierre ( $A$ revolução jacobina), extrai disso consequências extremas quando escreve: "dado que a alma da revolução é a virtude [...] segue-se que a primeira regra da política é endereçar todas as nossas energias para a manutenção e o desenvolvimento da virtude [...] tudo o que é imoral é impolítico".

Muitos ideais do republicanismo são levados em consideração na visão liberal de Immanuel Kant. Sua concepção de estado civil é baseada em três princípios: liberdade, igualdade e independência do indivíduo enquanto homem, súdito e cidadão, respectivamente. A independência concretiza-se, assim, na ideia de que todo o povo deva participar do processo legislativo. A "insociável sociabilidade" humana faz com que o estado de paz entre os homens não seja natural, mas deva ser instituído: esse é o papel da política, que o opera através do direito, criando o Estado (civitas), que é "a reunião de um certo grupo de homens sob leis jurí- 
dicas" (Metafísica dos costumes: 179). Em sua visão ideal da política, exposta no projeto À paz perpétua, todo o Estado deveria ter uma constituição republicana e deveria estar inserido em um sistema federal de Estados entre os quais vigore um direito cosmopolítico. Sua visão racionalista e iluminista, profundamente liberal, da política emerge com clareza na ideia de que também seja possível construir um Estado com "um povo de diabos", desde que sejam dotados de inteligência: o problema consiste, de fato, em imaginar um sistema constitucional de leis tão refinado a ponto de neutralizar cada uma das vontades perversas dos contraentes que secretamente gostariam de se subtrair à sua coação, mas que racionalmente reconhecem sua utilidade. Assim, aparece claramente como Kant confere à política e ao Estado a tarefa de regular as transações entre os homens de modo que estes vivam pacificamente, sem se propor a melhorá-los moralmente: a política também pode existir entre um povo de diabos, porque ela não requer uma estreita adesão à lei moral (imperativo categórico) e sim o mero conformismo ao direito (o imperativo hipotético típico da legalidade).

A contribuição mais significativa e inovadora dos Republicanos americanos ao pensamento político é constituída seguramente pela teoria do "alargamento de órbita", exposta por Alexander Hamilton (n. 9), que inverte as diretrizes da ciência política europeia, especialmente de Rousseau e Montesquieu, segundo as quais a República seria uma forma de governo adequada apenas para pequenas comunidades políticas. Hamilton, ao contrário, sustenta que a grande extensão territorial, o consequente maior número de partidos e variedade de interesses da nova União permitirá suprimir mais eficazmente as facções com o resultado de salvaguardar a paz interna. Com espírito clássico, ele também estigmatiza a "violência das facções" que, independentemente de constituir uma maioria ou uma minoria da população, está sempre em conflito com "os interesses permanentes e complexos da comunidade" (n. 10). Portadores de uma antropologia realista, eles identificam o surgimento das facções por características próprias da natureza humana e, mais especificamente, pela desigual distribuição de riqueza. Com isso, Madison entende que deverá ser tarefa da "legislação moderna" a regulamentação dos diferentes interesses. Distante de qualquer ideal de democracia direta, eles afirmam que o povo deverá agir politicamente "através da mediação de um corpo escolhido de cidadãos" (n. 10). Sob seu ponto de vista, em democracia o povo governa diretamente e, portanto, essa forma de governo é limitada 
às comunidades de pequenas dimensões, enquanto a República não tem limites territoriais. "O edifício da nação americana deverá apoiar-se sobre a sólida base do consenso do povo" (n. 22). Teoria dos poderes implícitos para fazer frente à variedade das eventualidades na política, que não têm limites. Eles concebem a política como identificação dos interesses permanentes de uma comunidade.

Em Alexis de Tocqueville verificamos um retorno ao realismo de Maquiavel no estudo das Repúblicas democráticas: em suas páginas brilha uma inspirada consciência da inevitabilidade do destino democrático dos Estados europeus juntamente com uma lúcida visão dos potenciais perigos que se escondem nas democracias. Ele teme principalmente o "despotismo paterno" que leva ao fim da política, ao mesmo tempo que também tira dos cidadãos "a preocupação de pensar e o sofrimento de viver" (Democracia na América II, 4, 6)

\section{Bibliografia}

AA.VV - "Materiali per un lessico politico europeo: Política". In Filosofia Política, 3 [1989] p.17-73.

AA.VV - Política. Venezia: Marsílio, s.d.

ARENDT, Hannah. - Vita activa. Milano: Bompiani, 1989.

BOBBIO, Norberto - Política. In BOBBIO, N.; MATTEUCCI, N. (eds) - Dizionario di política. Torino: Utet, 1976. p. 728-737.

CRICK, Bernard - Difesa della politica. Bologna: Il Mulino, 1969.

MATTEUCCI, Nicola - Alla ricerca dell'ordine político. Bologna: Il Mulino, 1984.

MATTEUCCI, Nicola - "Voce Política". In Enciclopedia delle scienze sociali. Vol.VI. Roma: Istituto dell'Enciclopedia Italiana, 1995, p.607-616; ora in Id. Lo Stato moderno. Bologna: Il Mulino, 1997, p. 295-320.

PASSERIN D'ENTRÈVES, Alessandro - Dottrina dello Stato. Torino: Giappichelli, 1962.

SCHMITT, Carl - Le categorie del "politico". Bologna: Il Mulino, 1972.

VIROLI, Maurizio - Dalla politica alla ragion di Stato. Roma: Donzelli, 1994. 